\title{
STRATEGI PENGEMBANGAN PRODUK KERUPUK OPAK MINANG YOLANDA
}

\author{
Fauzia Agustini $^{1}$, Dita Amanah*2 ${ }^{2}$, Dedy Ansari Harahap ${ }^{3}$ \\ ${ }^{1}$ Program Studi Kewirausahaan, Universitas Negeri Medan \\ ${ }^{2}$ Program Studi Pendidikan Bisnis, Universitas Pendidikan Indonesia \\ ${ }^{3}$ Program Studi Manajemen, Universitas Islam Bandung \\ e-mail:*ditaamanah@upi.edu
}

\begin{abstract}
This activity was carried out on SMEs producing snacks from sweet potatoes, namely opaque located in Medan under the name UD. Opak Minang Yolanda. Based on the observations, several problems were found, namely the texture is too fragile so it breaks easily, the taste has only one taste (original taste), the size is too large and the packaging is too simple. This activity is intended to assist UD. Opak Minang Yolanda in solving the main problems as described previously.The specific target in this activity is to improve product by diversifying products including texture, taste, size, packaging. The methods used in this activity are observations, interviews and seeking information from various literatures in the form of books, articles in journals, newspapers, relevant magazines and searching online. This activity also used a coaching pattern. The achievement of this study is the idea of opaque diversification for improvement in the sustainability of UD. Opak Minang Yolanda is an improvement in texture by thickening the volume of the opaque when formed, flavors made into various variants that are tailored to consumer tastes, sizes are made into two variants, namely large and small, making the packaging more attractive.
\end{abstract}

Keywords: observation; opaque; snacks

Abstrak : Studi ini dilakukan pada UMKM di Medan yang menghasilkan opak yaitu makanan ringan dari ubi dengan nama UD. Opak Minang Yolanda. Berdasarkan hasil observasi ditemukan beberapa permasalahan yaitu tekstur (permukaan) yang terlalu rapuh sehingga mudah pecah, hanya satu rasa yaitu original, ukuran (bentuk) yang terlalu besar dan kemasan (bungkus) yang terlalu sederhana. Kegiatan ini bertujuan untuk membimbing UD. Opak Minang Yolanda dalam menyelesaikan kesulitan utamanya seperti yang diuraikan sebelumnya. Sasaran utama kegiatan ini adalah membenahi produk dengan diversifikasi produk meliputi tekstur, cita rasa, ukuran, kemasan. Metode yang dilakukan pada kegiatan ini adalah melangsungkan pengamatan, tanya jawab, dan menggali fakta-fakta dari berbagai referensi seperti buku, artikel pada jurnal, surat kabar, majalah yang relevan dan juga pencarian informasi secara online. Selain itu dilakukan pembinaan untuk merubah kualitas produk UD. Opak Minang Yolanda. Capaian luaran kegiatan ini adalah buah pikiran melalui diversifikasi opak untuk memperbaharui dan keberlanjutan UD. Opak Minang Yolanda yaitu pada tekstur dengan cara lebih menambah volume opak ketika dibentuk, cita rasa yang lebih bervarian yang disesuaikan dengan selera konsumen, ukuran menjadi 2 (dua) varian yaitu besar dan kecil serta menciptakan kemasan menjadi lebih menarik.

Kata kunci: makanan ringan; observasi; opak 


\section{PENDAHULUAN}

Pengelolaan setiap bisnis tidak pernah luput dari masalah. Setiap saat berkemungkinan akan muncul berbagai masalah dan masalah harus dihadapi dan diselesaikan, bukanlah untuk dihindari. Masalah muncul disebabkan oleh keadaan yang tidak sesuai dengan harapan, sehingga pencapaian tujuan akan terhambat. Oleh sebab itu setiap masalahmasalah yang muncul harus dicari penyelesaiannya dengan sebaik mungkin.

Pemecahan masalah yang dihadapi pelaku usaha memerlukan ide kreatif dan inovasi produk usaha yang ditujukan untuk menarik minat pelanggan, yaitu dengan melakukan pengembangan produk pada sektor industri makanan ringan (Amanah, Agustini, Rambe, \& Harahap, 2019).

Produk adalah barang atau jasa yang ditawarkan dan diperjualbelikan yang dapat memuaskan keinginan atau kebutuhan konsumen (Pichler, 2020). Salah satu elemen strategi pemasaran yang merupakan penentu pencapaian suatu usaha adalah produk, untuk itu produk yang dihasilkan harus disesuaikan dengan selera, keinginan dan kebutuhan pasar atau konsumen (LeMay, 2017).

Kemenarikan tampilan produk memerlukan edukasi dan pelatihan pengambilan foto produk yang gunanya adalah untuk dokumentasi usaha. Foto tersebut kemudian ditayangkan dan disebarkan di media sosial (online), diantaranya facebook dan instagram. Era digital dan perkembangannya saat ini tidak dapat terhindarkan dan harus disesuaikan oleh kondisi setiap bisnis dengan menyesuaikan strategi pemasarannya, salah satunya dengan sistem bisnis online sebagai cara penjualan produk saat ini (Harahap \& Amanah, 2018).
UD. Opak Minang Yolanda merupakan salah satu industri rumahan yang mengasilkan opak, terletak di Jalan Pelajar Timur No. 217 A Medan. Usaha rumahan ini telah dirintis oleh ibu Roslinda sejak tahun 2013 dan masih berjalan hingga sekarang. Usaha opak merupakan usaha yang tidak memerlukan banyak karyawan. Untuk itu dalam menjalankan usaha UD. Opak Minang Yolanda hanya melibatkan tenaga seluruh anggota keluarga yang berjumlah 6 (orang) orang untuk ikut andil dalam usaha, sehingga menghemat biaya tenaga kerja, karena upah yang di berikan kepada anggota keluarga tidak terlalu besar. Cara memproduksi opak tersebut juga masih tradisional. Harga untuk satu bungkus opak sebesar Rp. 8.000,00 dengan isi setiap bungkus sebanyak 10 keping. Dalam sehari Opak Yolanda dapat menjual paling banyak 20 bungkus dan paling sedikit 10 bungkus.

Pendapatan satu bulan usaha opak ini tidak menentu, karena tergantung dari permintaan pasar yang beragam. Selera konsumen yang beragam tidak dapat ditebak, kadangkala ada konsumen yang tidak menyukai kerupuk opak dikarenakan ukurannya yang dianggap besar. Untuk itu perlu dilakukan pendesainan ulang produk opak untuk menyesuaikan dengan keinginana konsumen yang sangat bervariasi. Cara promosi yang tidak memiliki tempat tetap juga menjadikan usaha opak ini mendapat kendala.

UD. Opak Minang Yolanda hanya menyalurkan dagangannya ke sekitar rumah, sehingga mereka belum memiliki pelanggan tetap. Setiap hari usaha ini mensuplai ke warung, rumah makan, food court. Hal ini dikarenakan kurangnya promosi sehingga lokasi pendistribusian hanya sebatas area tempat usaha UD. Opak Minag Yolanda. 
Berdasarkan hasil observasi yang sudah dilakukan, Opak Yolanda ini lebih mudah hancur (rapuh) dibandingkan opak lainnya, adapun alasan yang diberikan adalah untuk mempermudah proses pengeringan opak tersebut, namun hal ini menyebabkan opak mudah hancur serta memerlukan tempat penyimpanan tersendiri yang khusus untuk menjaga kerapuhannya.

Praktik bisnis yang dijalankan pelaku usaha dalam memasarkan produknya saat ini telah dipengaruhi dan diubah oleh digitalisasi. Strategi pemasaran perusahaan harus menyesuaikan dengan era digital melalui perubahan saluran pemasaran agar perusahaan dapat menjangkau pelanggan yang lebih luas (Harahap, 2020a). Diperlukan suatu teknik dan strategi pemasaran yang komprehensif yang nantinya akan diterapkan pelaku usaha dalam menangani rintangan pemasaran dalam dunia usaha (Palmatier \& Sridhar, 2017). Strategi pengembangan produk merupakan salah satu komponen yang diperlukan dalam menjalankan bisnis, yaitu menciptakan produk semenarik mungkin yang didasarkan kepada budaya, pengalaman unik dan promosi (Harahap, Hurriyati, Gaffar, \& Amanah, 2019). Usaha Mikro, Kecil dan Menengah seperti opak (sejenis makanan ringan kerupuk) menjadi sektor paling sensitif terdampak pukulan pandemi virus covid19 dimana kebutuhan dan keinginan konsumen yang semakin beragam menggeser pola penjualan oleh pelaku usaha dalam melakukan pemasarannya (Harahap \& Amanah, 2020; Harahap, 2020b).

Riset pemasaran memang seyogianya dilakukan pelaku usaha untuk memperoleh analisis mendalam mengenai keinginan dan kebutuhan pelanggan (Aaker, Kumar, Day, \& Leone, 2009).
Konsumen memerlukan penciptaan nilai yang tinggi yang diberikan pemasar kepada mereka, seperti yang ada pada prinsip dasar pemasaran. Perusahaan harus mampu bersaing dengan keunggulannya dan fokus terhadap penyegeraan penyelesaian masalah sekiranya ditemukan. Oleh sebab itu setiap pelaku usaha harus selalu dapat mengevaluasi dan berfikir untuk menghasilkan produk yang sesuai dengan permintaan pasar (Kotler, Armstrong, \& Harris, 2019). Solusi yang dapat diberikan untuk UD. Opak Minang Yolanda yaitu memperbaiki hasil produk dengan melakukan inovasi baru seperti melakukan diversifikasi produk yang meliputi, tekstur, cita rasa, ukuran dan kemasan opak.

\section{METODE}

Lokasi mitra berada pada Jalan Pelajar Timur (depan Komplek Griya UNIMED), kecamatan Medan Kota, kota Medan, Sumatera Utara, 20226. Kegiatan ini dilakukan selama 2 (dua) bulan yang dimulai pada 10 Agustus sampai 30 Oktober 2020. Dalam penelitian terhadap UMKM UD. Opak Minang Yolanda, metode yang digunakan yaitu sebagai berikut:

Observasi Langkah awal dalam kegiatan ini adalah melakukan obervasi mengenai kegiatan UD. Opak Minang Yolanda. Aktivitas ini meliputi pengamatan mengenai proses awal sampai akhir pembuatan opak yang bertujuan untuk memahami fakta di lapangan sehingga diperoleh informasi untuk penelitian selanjutnya. Selanjutnya Wawancara, Pemahaman lebih baik mengenai kegiatan usaha ini dilakukan dengan melakukan wawancara yang merupakan aktivitas utama dalam 
penelitian observasi yaitu berupa tanya jawab secara lisan kepada pelaku usaha yang diharapkan dapat memperoleh informasi yang diperlukan peneliti. Wawancara berkenaan dengan sejarah usaha, proses produksi, serta cara pendistribusian opak hingga sampai ke tangan konsumen.

Penelitian ini juga memanfaatkan metode lain dalam mencari informasi yang relevan seperti buku yang Terkait dengan materi pemasaran dari buku Philip Kotler, peneliti mengambil informasi mengenai teori produk, dan internet mengambil informasi mengenai diversifikasi produk khususnya pencarian mengenai opak yang memiliki rasa bervariasi, kemasan opak yang menarik, serta gambar berbagai macam ukuran dan bentuk opak yang nantinya akan disarankan kepada pelaku usaha.

\section{PEMBAHASAN}

Keberagaman selera konsumen terhadap suatu produk dapat menjadi suatu peluang bisnis yang menjanjikan. Ud Opak Minang Yolanda dapat memanfatkan peluang tersebut dengan melakukan perombakan ulang pada produk opaknya dengan membuat diversivikasi produk yang meliputi :

\section{Tekstur}

Tekstur merupakan bentuk khusus dari suatu produk yang mengindikasikan kualitas. Bentuk dari suatu produk dapat bervariasi (Dar \& Light, 2014). Tekstur dari opak yang dihasilkan UD.Opak Minang Yolanda sangat mudah rapuh, namun setelah dibimbing, kualitas opak ditingkatkan, dengan lebih mempertebal volume opak saat dicetak atau dibentuk. untuk itu perlu dilakukan peningkatan kualitas dengan perubahan bahan olahan yang digunakan agar opak tersebut tidak mudah rapuh. Tujuan mengevalusi kembali bahan yang digunakan adalah agar dalam pendistribusian opak ini ke penitipan seperti warung-warung kecil (grosir), warung sate dan rumah makan tidak mengalami kerusakan sehingga akan mengurangi nilai jual atau bahkan ditolak oleh pihak yang akan menjualnya (Gambar 1).

\section{Cita Rasa}

Cita rasa merupakan cara memilih makanan termasuk di dalamnya rasa, suhu, tekstur, bau, tampilan (Tepper \& Barbarossa, 2020). Cita rasa opak Yolanda yang sebelumnya hanya memiliki satu rasa, sekarang sudah dapat dibuat dengan berbagai varian sesuai dengan selera konsumen. Varian rasa ini dapat dilakukan dengan menambahkan beberapa bahan utama pada adonan opak untuk menciptakan rasa baru seperti penambahan udang yang telah dihaluskan untuk menciptakan opak rasa udang atau penambahan bumbu BBQ untuk menciptakan rasa BBQ. pemilik usaha dapat membuatnya dengan berbagai varian rasa yang sesuai dengan selera konsumen. Selera konsumen yang berbeda beda tentu dapat dijadikan peluang bagi UD. Opak Minang Yolanda untuk lebih mengembangkan usahanya (gambar 2).

\section{Ukuran}

Ukuran merupakan struktur fisik, bentuk, model produk yang berwujud dan dapat diukur. Ukuran produk dapat dijadikan salah satu identitas dan menjadi daya tarik khusus bagi pelanggan (Millot, 2018). Ukuran opak UD. Opak Minang Yolanda yang selama ini dianggap besar, sekarang dicetak menjadi 2 (dua) jenis ukuran yaitu kecil dan besar (Gambar 3). Ukuran ini disesuaikan dengan selera 
target pasar yang ingin dicapai. Minat beli tentu lazimnya didasarkan kepada ketertarikan kepada ukuran produk (Whang, 2015).

\section{Kemasan}

Kemasan (packaging) adalah bagian luar atau bungkus produk yang berfungsi melindungi produk sehingga tetap terjaga kualitasnya (Breetz, 2014). Kemasan opak yang awalnya sederhana tanpa label akan diubah menjadi kemasan yang lebih menarik serta bermanfaat dengan penambahaan label pada kemasan untuk menunjukkan identitas UD. Opak Minang Yolanda sehingga mempermudah konsumen untuk mencari UD. Opak Minang Yolanda apabila konsumen ingin memesan dalam jumlah banyak atau ada keperluan lain yang diharapkan bermanfaat bagi usaha ini.

Kemasan yang digunakan UD. Opak Minang Yolanda sangat sederhana, sehingga tidak memiliki daya tarik tersendiri bagi pelanggan. Identitas produsen juga tidak terlihat pada luar atau di dalam kemasan, untuk itu agar lebih menarik minat konsumen perlu dilakukan perancangan ulang kemasan serta pemberiaan identitas produsen pada kemasan untuk menarik minat pelanggan.
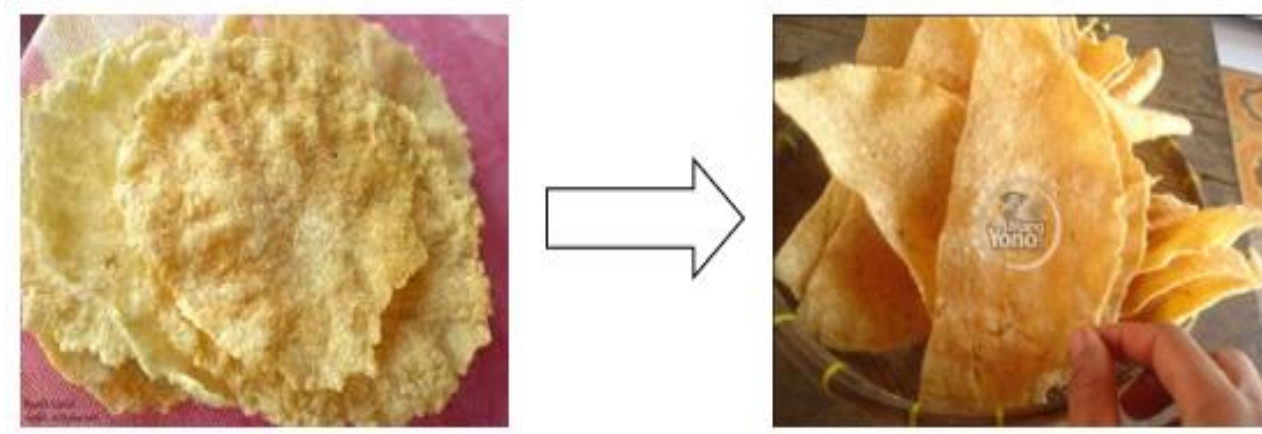

Gambar 1. Tekstur opak yang lama (kiri) dan tekstur opak yang baru (kanan)
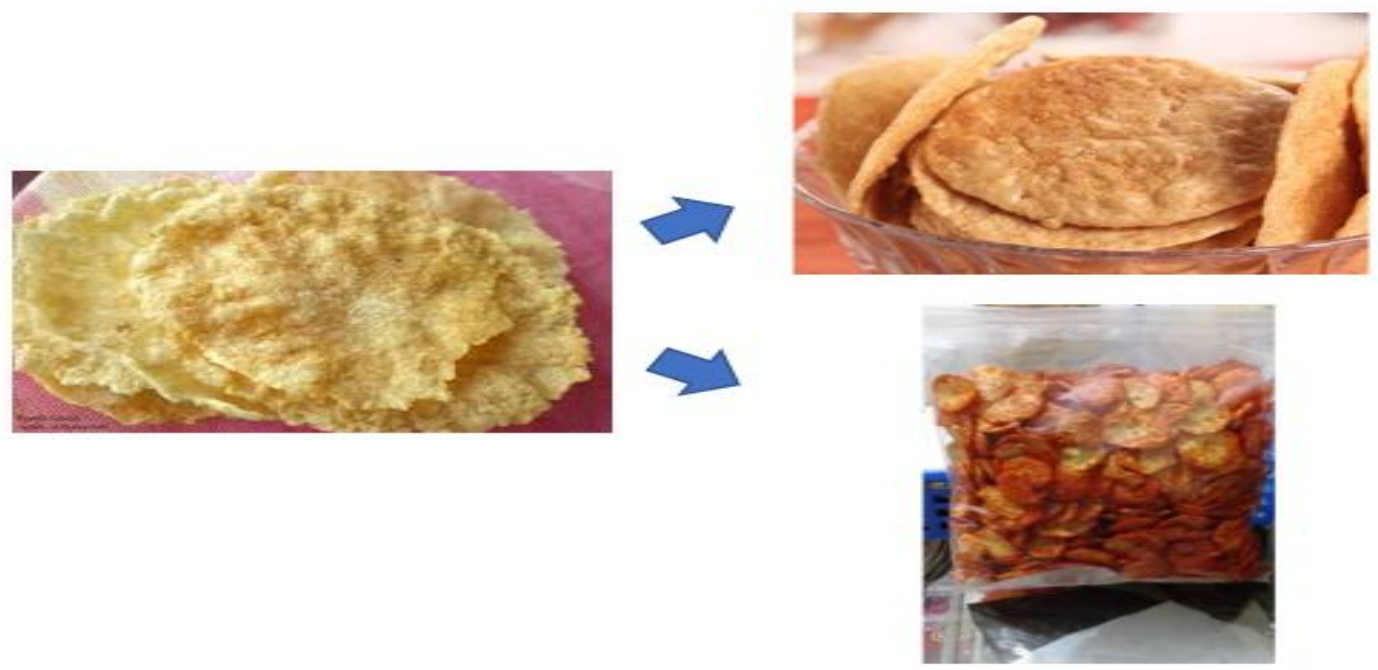

Gambar 2. Rasa Opak Original (kiri),Rasa Opak Udang (kanan atas) dan BBQ (kanan bawah) 
Jurdimas (Jurnal Pengabdian Kepada Masyarakat) Royal

Vol. 4 No. 3, September 2021, hlm. 293 - 300
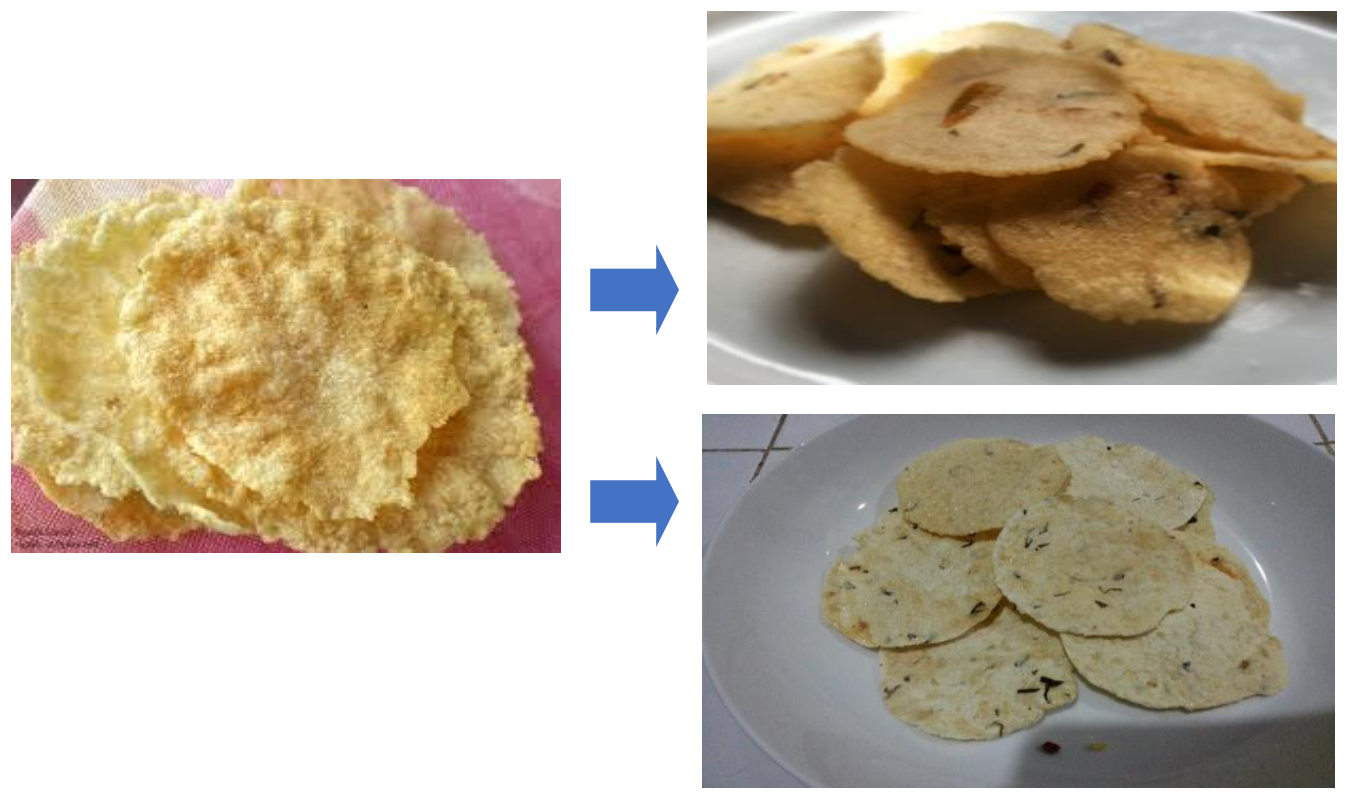

\section{Gambar 3. Ukuran Opak Besar (kiri) dan Ukuran Opak Yang Lebih Kecil (kanan atas dan bawah)}
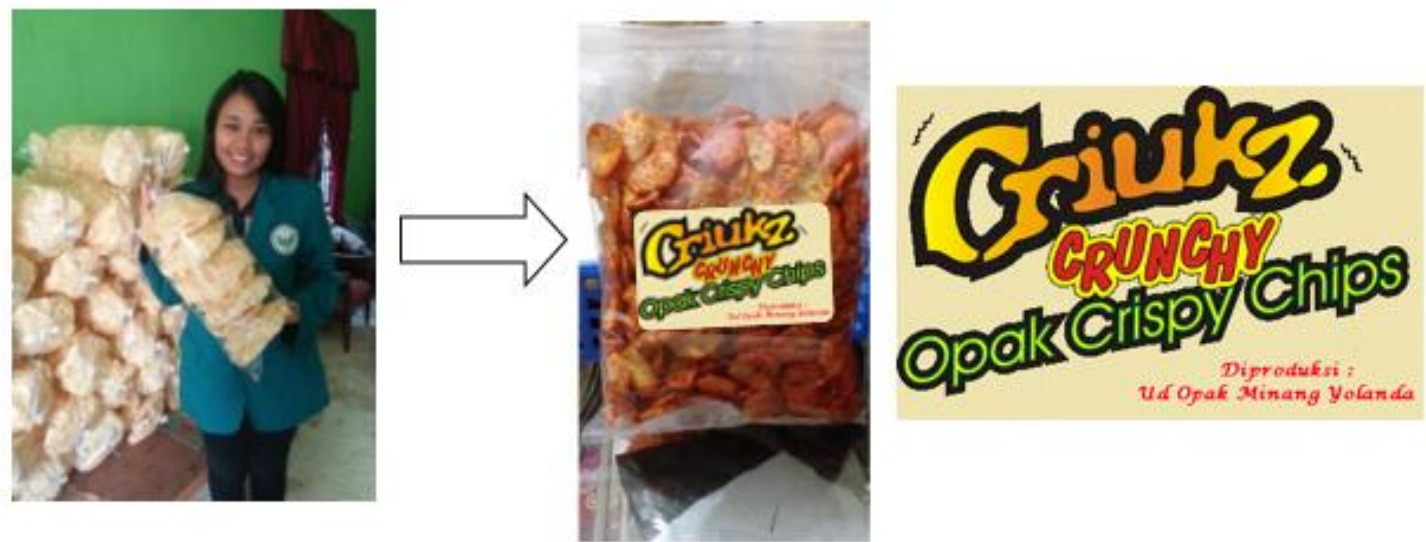

Gambar 4. Kemasan Opak Lama (kiri) dan Inovasi Kemasan Baru Opak (kanan)

\section{SIMPULAN}

Dengan melakukan pembinaan dan pembimbingan, maka pemilik usaha menerima usulan diversivikasi produk yang dilakukan untuk memperbaiki opak tersebut meliputi tekstur opak, cita rasa opak, ukuran opak dan bungkus atau kemasan opak. tersebut dan dilakukan perubahan pada keempat unsur tersebut.
Sistem pen-distribusian opak menjadi berubah dimana sebelumnya hanya disalurkan di sekitar rumah, sekarang dapat disuplai ke warung makan, foodcourt dan grosir. Dengan demikian usaha UD. Opak Minang Yolanda dapat berkembang dan lebih maju serta meningkatkan penjualan. 


\section{DAFTAR PUSTAKA}

Aaker, D. A., Kumar, V., Day, G. S., \& Leone, R. (2009). Marketing Research. New Jersey: Wiley.

Amanah, D., Agustini, F., Rambe, A., \& Harahap, D. A. (2019). PKM Penenun di Desa BarungBarung Kecamatan Lima Puluh Kabupaten Batubara. Pelita Masyarakat, 1(September), 615.

Arsyah, R. H., \& Juwita, A. I. (2021). Konvergensi Media dalam Pemasaran Produk Kerajinan Masyarakat desa Wisata Pariangan. Jurdimas (Jurnal Pengabdian Kepada Masyarakat) Royal, 4(1), 59-64. https://doi.org/10.33330/jurdima s.v4i1.948.

Breetz, C. (2014). Product packaging as tool to demand a price premium: Does packaging enhance consumers' value perception to justify a price premium. Hamburg: Anchor Academic Publishing.

Dar, Y. L., \& Light, Joseph M. (2014). Food Texture Design and Optimization. New Jersey: Wiley.

Harahap, D. A. (2020a, April). Pentingnya Komunikasi Pemasaran Menciptakan Kesadaran Merek. Opinions Info Brand, (April), 1. Retrieved from https://infobrand.id/pentingnyakomunikasi-pemasaranmenciptakan-kesadaranmerek.phtml

Harahap, D. A. (2020b, May 12). Virus Corona dan Beralihnya Pedagang Tradisional ke Online. Opini Harian Pelita, pp. 1-2.
Retrieved from http://harianpelita.co/2020/05/12 /virus-corona-dan-beralihnyapedagang-tradisional-ke-online/

Harahap, D. A., \& Amanah, D. (2018) Perilaku Belanja Online di Indonesia: Studi Kasus. Jurnal Riset Manajemen Sains Indonesia, 9(2), 193-213. https://doi.org/doi.org/10.21009/ JRMSI.009.2.02

Harahap, D. A., \& Amanah, D. (2020). Determinants of Consumer Purchase Decision in SMEs. International Journal of Scientific \& Technology Research, 9(3), 3981-3989.

Harahap, D. A., Hurriyati, R., Gaffar, V., \& Amanah, D. (2019). Culinary Tourism in Indonesia-Empirical Study at Amaliun Food Court , Medan. SAR Journal, 2(1), 1523.

https://doi.org/10.18421/SAR21 $-03$

Kotler, P., Armstrong, Gary, \& Harris, Lloyd C. (2019). Principles of Marketing. London: Pearson Education.

LeMay, M. (2017). Product Management in Practice: A Real-World Guide to the Key Connective Role of the 21st Century. California: O'Reilly Media, Inc.

Millot, M. (2018). Embarrassment of Product Choices 1: How to Consume Differently. New Jersey: Wiley.

Palmatier, R. W., \& Sridhar, S. (2017). Marketing Strategy: Based on First Principles and Data Analytics. London: Macmillan International Higher Education.

Pichler, R. (2020). How to Lead in Product Management: Practices to Align Stakeholders, Guide 
Jurdimas (Jurnal Pengabdian Kepada Masyarakat) Royal

Vol. 4 No. 3, September 2021, hlm. 293 - 300

Available online at https://jurnal.stmikroyal.ac.id/index.php/jurdimas

Development Teams, and Create Value Together. London: Pichler Consulting.

Sari, R., Sayadi, M. H., \& Hildayanti, S. K. (2020). Pelatihan Dalam Menghadapi Tantangan Usaha Kecil Di Era Digital Pada Pelaku Usaha Kecil Di Kenten Palembang. Jurdimas (Jurnal Pengabdian Kepada Masyarakat) Royal, 3(2), 87-92. https://doi.org/10.33330/jurdima s.v5i3.575.

Tepper, B. J., \& Barbarossa, Iole T. (2020). Taste, Nutrition and Health. Switzerland: MDPI AG.

Whang, S. M. (Leo). (2015). The New Consumer Psychology: Scanning buying behavior with The MRI of The Mind. United Kingdom: Francis\&Taylor. 